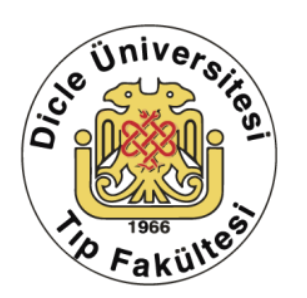

\title{
Kronik Böbrek Yetmezliği Olan Hastalarda Antihipertansif İlaç Tedavisine Uyum Oranları ve Etkileyen Faktörlerin Araştırılması
}

\author{
Burkay Yakar'1, Mustafa Demir ${ }^{2}$ \\ 1 Fırat Üniversitesi Tıp Fakültesi, Aile Hekimliği AD, Elazığ, Türkiye, ORCID: 0000-0003-2745-6561 \\ 2 Fırat Üniversitesi Tıp Fakültesi, Nefroloji BD, Elazığ, Türkiye, ORCID: 0000-0001-6798-1956
}

Geliş: 03.05.2019; Revizyon: 15.08.2019; Kabul Tarihi: 19.09.2019

\section{$\ddot{0} \mathbf{z}$}

Giriş ve Amaç: Hipertansiyon kronik böbrek hastalığının en önemli nedenlerinden birisi olmasının yanında son dönem böbrek yetmezliğine ilerlemesine de neden olabilmektedir. Etkin antihipertansif tedavinin Kronik böbrek hastalığının son dönem böbrek yetmezliğine ilerleyişi yavaşlattığı bilinmektedir. Günümüzde hipertansiyonun neden olduğu komplikasyonları önlemede ki en önemli etkenlerin başında antihipertansif tedaviye uyum gelmektedir. Araştırmamızda antihipertansif tedavinin daha fazla önem arz ettiği kronik böbrek hastalarının tedaviye uyum durumları ve etkileyen faktörlerin araştırılması amaçlanmıştır.

Yöntemler: Tanımlayıcı ve kesitsel tipteki araştırmamızın evrenini kronik böbrek yetmezliği ve hipertansiyon nedeni ile takip edilen 150 hasta oluşturmuştur. Katılımcıların antihipertansif tedaviye uyumunu değerlendirmek için Türkçe Modifiye Morisky Ölçeği (TMMÖ) kullanılmıştır. Çalışmadan elde edilen kategorik veriler SPSS 22.0 paket program kullanılarak Ki-kare testi ile değerlendirilmiştir.

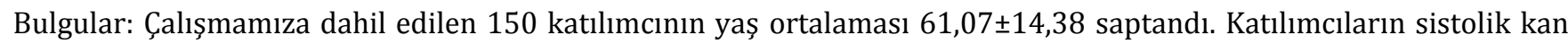

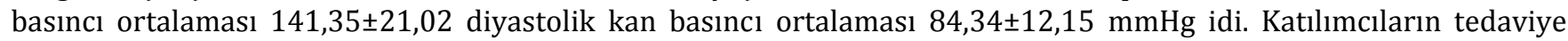
uyum oranı \%70,6 HT bilgi düzeyi yeterli olanların oranı ise \%73,3 idi. Eğitim düzeyi düşük olanlarda, HT bilgi düzeyi düşük olanlarda ve 65 yaş üzeri katılımcılarda antihipertansif tedaviye uyum oranı daha düşük bulundu.

Sonuç: Antihipertansif tedaviye uyum oranı özellikle eğitim düzeyi ve HT bilgi ve farkındalığının düşük olduğu grupta yetersiz olduğundan hasta eğitimi ile hem ilaç uyumunun arttırılabileceği böylelikle hastaları HT’un komplikayonlarından koruyabileceğimiz kanaatindeyiz.

Anahtar kelimeler: Hipertansiyon, Kronik böbrek yetmezliği, antihipertansif tedavi uyum, Modifiye Morisky Ölçeği. 


\title{
Evaluation of Adherence to Antihypertensive Drug Treatment Affecting Factors in Patients with Chronic Renal Failure
}

\begin{abstract}
Objective: Hypertension is one of the most important causes of chronic kidney disease and may cause it to progress to end-stage renal disease. Effective antihypertensive therapy is known to slow the progression of chronic renal disease to end-stage renal failure. Today, antihypertensive treatment is the most important factor in preventing the complications caused by hypertension. In our study, it was aimed to investigate treatment adaptation status and the factors affecting chronic renal failure patients in which antihypertensive treatment is important.

Method: The population of our descriptive and cross-sectional study was composed of 150 patients with chronic renal failure and hypertension. Turkish Modified Morisky Scale (TMMS) was used to evaluate the adaptation of participants to antihypertensive treatment. Categorical data obtained from the study were evaluated by using Chi-square test using SPSS 22.0 package program.

Results: The mean age of 150 participants included in our study was $61.07 \pm 14,38$ years. The mean systolic blood pressure of the participants was $141.35 \pm 21.02$ and diastolic blood pressure was $84.34 \pm 12.15 \mathrm{mmHg}$. The rate of patients' adherence to treatment was $70.6 \%$ and the rate of knowledge with HT was $73.3 \%$. The rate of adherence to antihypertensive treatment was found to be lower in the subjects with low education level, in those with low level of HT knowledge and in the participants over 65 years of age.

Conclusion: As the rate of adherence to antihypertensive treatment is insufficient, especially in the level of education and low knowledge and awareness of HT, we believe that adherence to treatment can be increased with patient education so protecting patients from complications of HT.
\end{abstract}

Keywords: Antihypertensive treatment, Chronic renal failure, Adherence, Hypertension

\section{GíRIŞ}

Hipertansiyon en sık görülen kardiyovasküler hastalıktır. Tüm dünyada önlenebilir ölüm nedenleri arasında bir numaralı risk faktörü olduğu için önemli bir toplum sağllğ sorunudur ${ }^{1}$. Amerika Birleșik Devletleri 20112014 hipertansiyon sıklığı ve kontrol çalışması verilerinde hipertansiyon prevalansı 18-39 yaş arası \%7,3, 40-59 yaș arası \%32,2 ve 60 yaș üzeri sıllı̆̆l ise \%64,9 olarak bildirilmiștir². Ülkemizde 2012 yılında yapılan araștırmada ise erişkin nüfusta hipertansiyon prevalansı \%30,3 olarak bildirilmiștir ${ }^{3}$.

Hipertansiyonun prevalansının sik olmasının yanı sıra dünyada önlenebilir ölüm nedenleri arasında en bașta gelen risk etmenidir ${ }^{4}$. Kalp hastalıklarına bağlı ölümlerin \%45'inden, inmeye bağlı ölümlerin \%51'inden hipertansiyon sorumlu olup, etkin kan basıncı kontrolü ile bu risklerin azaltılabileceğine işaret edilmektedir ${ }^{5,6}$.
Günümüzde hipertansiyon kontrolü ve tedavisinde ilerleme kaydedilmesine rağmen hala hastaların ilaç almayı unutma, ilaçları doğru kullanamama ve randevularını kaçırma gibi davranışlarından dolayı etkin kontrol sağlanamamaktadır ${ }^{7}$. Hipertansif hastaların yaklaşı 2/3'ünde kan basıncı kontrolü sağlanamadığı ve bu hastaların 1/3'ünün hipertansiyon ilaçlarını hiç kullanmamak ya da önerildiği gibi kullanmamak gibi alışkanlıklar gösterdiği görülmüştür8,9. İlaç kullanmamanın başlıca nedeni, sürekli ilaç kullanmaya uyum sağlamadaki güçlük olarak gösterilmektedir. Tedaviye uyumsuzluğun sonucunda ise komplikasyonların ve sağlık harcamalarının arttığı bildirilmiştir ${ }^{10}$.

Antihipertansif tedaviye uyumu etkileyen faktörlerin araștırılması ve tedaviye uyumu arttırıcı önlemler hipertansiyon hastalığının tedavisinin ve komplikasyonlarının azaltılmasında ki en önemli faktör olarak 
görülmektedir. Antihipertansif tedaviye uyumsuzluğun hipertansiyonun kontrolündeki başarısızlıkta önemli bir rol oynamasına rağmen çoğunlukla tedaviye uyumun değerlendirilmesi ihmal edilmektedir ${ }^{11,14}$.

$\mathrm{Bu}$ bağlamda yaplan araştırmalara baktığımızda bireylerin hastalığına verdiği önem kişilerin sağlık bilgisinden etkilendiği ve hastaların antihipertansif ilaçların yararlarını bilmelerinin tedaviye uyumu etkilediği gösterilmiştir ${ }^{15}$. Ülkemizde yapılan bir araştırmada ise kırsal alanda yaşayanlarda hipertansiyon yönetimi için yeterli bilgi, beceri ve davranışa sahip olmadıkları ve dolayısı ile antihipertansif tedaviye uyumlarının kentsel nüfusa göre daha olumsuz olduğu gösterilmiştir ${ }^{16}$.

Kronik böbrek hastalığ dünya genelinde popülasyonun \%10-15'ini etkilediği ve prevalansının giderek arttı̆̆ bildirilmiştir ${ }^{17}$. Avrupa Hipertansiyon Derneği hipertansiyonun kronik böbrek hastalığı olan popülasyonun $\% 90$ 'ını etkilediğini bildirmiștir ${ }^{18}$. Hipertansiyon diabetes mellitusdan sonra en önemli Kronik böbrek hastalığı sebebi olarak bildirilmiştir ${ }^{18}$. Hipertansiyon kronik böbrek hastalığının nedenlerinden birisi olmasının yanında hastalığın ilerlemesine de katkıda bulunduğu bildirilmiștir ${ }^{19}$.

Etkin antihipertansif tedavinin Kronik böbrek hastalığının son dönem böbrek yetmezliğine ilerleyiş̧i yavaşlattığı bilinmektedir ${ }^{20}$. Bu yüzden kronik böbrek hastalarında antihipertansif tedavi ve tedaviye uyum daha bir önem kazanmaktadır.

Literatürde antihipertansif tedaviye uyum ile ilgili çalışmalar mevcut iken antihipertansif tedavinin daha fazla önemli olduğu kronik böbrek hastalarında antihipertansif tedaviye uyum ile ilgili yeterince çalışma yoktur. $\mathrm{Bu}$ bağlamda araştırmamızda kronik böbrek hastalığı olan popülasyonda antihipertansif tedaviye uyum oranlarını araştırmak, antihipertansif tedaviye uyumu etkileyebilecek faktörleri saptamak amaçlanmıştır.

\section{YÖNTEMLER}

\section{Araştırmanın Tipi}

Tanımlayıcı-kesitsel tipte tasarlanan araştırmanın evrenini bir üniversite hastanesinin dahiliye-nefroloji polikliniğine başvuran kronik böbrek hastalığı nedeni ile takipte olan ve antihipertansif tedavi alan hastalar oluşturmuştur. Yaptığımız araştırmada 1 yıllık süre zarfında polikliniğimize çalışma kriterlerimize uyan ve kronik böbrek hastalığ nedeni ile takip edilen yaklaşık 300 kişinin başvurduğu görülmüștür. Evren büyüklüğünü 300 olarak kabul ederek $\mathrm{n}=\mathrm{N}$ t2 p q/ d2(N-1) + t2pq formülünden olayın görülme sıklığı $\% 30$ ve güven aralığı \%95 kabul edilerek evreni yansitacak örneklem büyüklügü 155 kişi olarak hesaplanmıştır ${ }^{13}$. Örneklem seçiminde polikliniğe başvuran çalışmaya katılmaya gönüllü ve araştırma kriterlerini karşılayanlar arasından rastgele örneklem seçimi yapılmıştır. Araştırmamı 160 katılımcıya ulaşılınca sonlandırılmıștır. Veri kontrolünde hatalı doldurulan 10 anket formu çalışmaya dahil edilmemiştir. Araştırmamız 150 katılımcı ile yapılmıştır.

\section{Araştırmaya alınma ölçütleri}

- 18 yaş ve üzeri olma,

- Bilinen kronik böbrek hastalığı olma

- En az 6 aydır hipertansiyon tanısı almış olma

- Antihipertansif tedavi başlanmış veya önerilmiş olma

- Çalışmaya katılmaya gönüllü olma

\section{Araştırmaya alınmama ölçütleri}

- İletişim problemi veya psikiyatrik tanısı bulunması

- 18 yaş altında olma

- İlaç kullanmaya engel mental ve psikiyatrik problemi olma 
- Anket formlarını yanlış veya eksik doldurma

- Kronik böbrek hastalığı ve hipertansiyonun birlikte bulunmaması

\section{Veri Toplama Araçları}

Araştırmamızda ilk olarak katılımcıların gönüllülük esasını dikkat alarak bilgilendirilmiş gönüllü olur formu ile katılımcıların olurları yazılı olarak alınmıştır.

Literatür verileri taranarak hazırladığımız 11 soruluk sosyodemografik anket formu ile katılımcların antihipertansif tedaviye uyumunu etkileyebilecek sosyodemografik özellikleri sorgulanmıștır.

Katılımcların antihipertansif tedaviye uyumunu değerlendirmek için Türkçe Modifiye Morisky Ölçeği (TMMÖ) kullanılmıştır. Vural ve ark. tarafından Türkçe'ye uyarlanan ve geçerlilik güvenirlik çalışması yapılan Türkçe Modifiye Morisky Ölçeğinin kısa, kolay uygulanabilir, motivasyon ve bilgi düzeyini ayrı ayrı değerlendirebilen güvenilir bir test olduğu bildirilmiş̦tir ${ }^{21}$. 6 Sorudan oluşan testte sorular Evet/Hayır olarak yanıtlanması istenmektedir. 2 . ve 5 . sorularda evet 1 puan, hayır ise 0 puan, diğer sorularda ise evet 0 puan, hayır 1 puan olarak hesaplanmıştır. 1,2 ve 6 . sorulardan hastanın aldığı toplam puan 0 veya 1 ise hastanın düşük motivasyon düzeyini, 1'den yüksek puan ise yüksek motivasyonu göstermektedir. 3,4 ve 5 . Sorulardan aldığ toplam puan 0 veya 1 ise hastalı ve tedavi hakkında düşük bilgi düzeyini, 1'den büyük değerler ise yüksek bilgi düzeyini göstermektedir.

\section{Veri Toplama}

Veriler katılımcılara gerekli açıklamalar yapıldıktan sonra katılımcıların kendileri tarafından doldurulan anket formları ile elde edilmiştir. Okuma yazma bilmeyen katılımcların ise anket formları araştırmacı tarafindan okunarak hastanın cevaplaması sağlanmıştır. Tüm katılımcıların kan basınçları en az 15 dakikalık dinlenme periyotu sonrası her iki koldan aneroid tansiyon aleti ile ölçüldükten sonra ortalamaları alınarak kayıt edilmiştir.

\section{Değişkenler}

Bağımsız Değişkenler: Sosyodemografik özellikler, sağlık/hastalık özellikleridir.

Bağımlı Değişkenler: Türkçe Modifiye Morisky Ölçeği toplam puanıdır.

\section{Verilerin Analizi}

Çalıșma sonucu elde ettiğimiz verilerin SPSS 22.0 programı ile hata kontrolleri, tabloları ve istatistiksel analizi yapılmıştır. Tanımlayıcı veriler yüzdeler ve ortalama \pm olarak verilmiştir. Kategorik verilerin analizinde Kikare testi (ve/veya Fisher's exact test) testi kullanılmıştır. Katılımcıların HT bilgi puanı ile antihipertansif tedaviye uyum puanı arasında ki ilişkinin istatistiksel analizinde Pearson korelasyon analizi kullanılmıştır. $\quad \mathrm{P}<0.05$ istatistiksel olarak anlamlı kabul edilmiştir.

\section{BULGULAR}

Çalışmaya dahil edilen 150 katılımcının yaş ortalaması 61,07 $\pm 14,38$ idi. Katılımcların sistolik kan basincı ortalaması 141,35 $\pm 21,02$, diyastolik kan basıncı ortalaması 84,34 $\pm 12,15$ mmHg idi. Katılımclların \%54,7'si (n=82) erkekti. Katılımcıların \%87,3'ü $(n=131) \mathrm{Kr}$. Börek hastalığı ve Hipertansiyona ilave ek bir hastalıkları olduğunu beyan etti. Katılımcıların $\% 48$ 'i $(n=72)$ hipertansiyon hastalı̆̆ının kontrolü için ilaç ve beslenme eğitimi aldıklarını bildirdi. Katılımclların sosyodemografik özellikleri tablo 1 'de sunulmuştur. 
Tablo 1. Katılımcıların sosyodemografik ve HT ile ilgili özellikleri

\begin{tabular}{|c|c|c|}
\hline Özellikler & Sayı (n) & Yüzde (\%) \\
\hline \multicolumn{3}{|l|}{ Cinsiyet } \\
\hline Kadın & 68 & 45,3 \\
\hline Erkek & 82 & 54,7 \\
\hline \multicolumn{3}{|l|}{ Eğitim düzeyi } \\
\hline Okuryazar değil & 35 & 23,3 \\
\hline Okuryazar & 32 & 21,3 \\
\hline İlköğretim & 48 & 32,0 \\
\hline Lise & 24 & 16,0 \\
\hline Yüksekokul & 11 & 7,3 \\
\hline \multicolumn{3}{|l|}{ Meslek } \\
\hline Ev hanımı & 58 & 38,7 \\
\hline Memur & 17 & 11,3 \\
\hline Asg.ücr/ serbest meslek & 37 & 24,7 \\
\hline Emekli & 34 & 22,7 \\
\hline Çalışmayan & 4 & 2,7 \\
\hline \multicolumn{3}{|l|}{ Aylık gelir algısı } \\
\hline Kötü & 45 & 30,0 \\
\hline Orta & 95 & 63,3 \\
\hline İyi & 10 & 6,7 \\
\hline \multicolumn{3}{|l|}{ Ek hastalık durumu } \\
\hline Var & 131 & 87,3 \\
\hline Yok & 19 & 12,7 \\
\hline \multicolumn{3}{|l|}{ Günlük alınan ilaç sayısı } \\
\hline 1 & 30 & 20,0 \\
\hline 2 & 19 & 12,7 \\
\hline 3 & 21 & 14,0 \\
\hline 4 & 16 & 10,7 \\
\hline 5 ve üzeri & 64 & 42,7 \\
\hline \multicolumn{3}{|c|}{ HT hastalığı için eğitim alma durumu } \\
\hline Eğitim alan & 72 & 48,0 \\
\hline Eğitim almayan & 78 & 52,0 \\
\hline \multicolumn{3}{|l|}{ Eğitimi veren kişi } \\
\hline Eğitim almayan & 79 & 52,7 \\
\hline hekim & 68 & 45,3 \\
\hline hemșire & 3 & 2,0 \\
\hline
\end{tabular}

\begin{tabular}{|lrr|}
\hline HT kontrol sıklığı durumu & & \\
Ayda 1 kez & 47 & 31,3 \\
3 ayda bir kez & 73 & 48,7 \\
6 Ayda bir kez & 10 & 6,7 \\
Yılda bir kez & 3 & 2,0 \\
Düzenli yaptırmayan & 17 & 11,3 \\
& & \\
Sistolik kan basıncı kontrol durumu* & \\
Kontrol altında olan & 58 & 38,7 \\
Kontrol altında olmayan & 92 & 61,3 \\
& & \\
$\begin{array}{l}\text { Diyastolik kan basıncı } \\
\text { durumu* } \\
\text { Kontrol altında olan }\end{array}$ & 78 & 52,0 \\
Kontrol altında olmayan & 72 & 48,0 \\
\hline
\end{tabular}

*Kan basıncı hedeflenen değer $<135 / 85$ mmHg olarak Kabul edildi.

Tablo 2. Katılımcıların antihipertansif tedavi bilgi düzeyi ve tedaviye uyum özellikleri

\begin{tabular}{|lll|}
\hline Özellikler & Sayı (n) Yüzde (\%) \\
\hline Antihipertansif tedavi bilgi düzeyi & \\
Yetersiz & 40 & 26,7 \\
Yeterli & 110 & 73,3 \\
& & \\
Antihipertansif tedaviye uyum & & \\
Düşük ilaç uyumu & 44 & 29,4 \\
Yüksek ilaç uyumu & 106 & 70,6 \\
Toplam & 150 & 100,0 \\
\hline
\end{tabular}

Katılımclların Modifiye Morisky Ölçeğine göre \%26,7'sinin HT bilgi düzeyinin yetersiz olduğu görüldü. Katılımclların antihipertansif tedaviye uyumsuzluk oranı ise \%29,4 idi (Tablo 2). 
Yakar B., Demir M.

Tablo 3. Katılımcıların bazı özelliklerinin antihipertansif tedavi uyumu ile ilişkisi

\begin{tabular}{|c|c|c|c|c|c|c|c|}
\hline Özellikler & $\begin{array}{l}\text { Düşü } \\
\text { uyum }\end{array}$ & $\begin{array}{l}\text { ik ilaç } \\
\text { nu }\end{array}$ & $\begin{array}{l}\text { Yükse } \\
\text { uyum }\end{array}$ & $\begin{array}{l}\text { ek ilaç } \\
\text { nu }\end{array}$ & Total & & İstatistik \\
\hline Cinsiyet & Sayı & Yüzde & Sayı & Yüzde & Sayı & $\begin{array}{l}\text { Yüz } \\
\text { de }\end{array}$ & \\
\hline Kadın & 25 & 36,8 & 43 & 63,2 & 68 & 45,3 & $P=0,07$ \\
\hline Erkek & 19 & 23,2 & 63 & 76,8 & 82 & 54,7 & \\
\hline Yaş & & & & & & & \\
\hline$<65$ yaş & 19 & 22,6 & 65 & 77,4 & 84 & 56.0 & $P=0.04$ \\
\hline$\geq 65$ yaş & 25 & 37,9 & 41 & 62.1 & 66 & 44.0 & \\
\hline $\begin{array}{l}\text { Ek kronik hast } \\
\text { durumu }\end{array}$ & alık es & şlik etn & & & & & \\
\hline Var & 38 & 29,0 & 93 & 71,0 & 131 & 87,3 & $\mathrm{P}=0.82$ \\
\hline Yok & 6 & 31,6 & 13 & 68,4 & 19 & 12,7 & \\
\hline Gelir algısı duı & umu & & & & & & \\
\hline Kötü & 14 & 31,1 & 31 & 68,9 & 45 & 30,0 & \\
\hline Orta & 28 & 29,5 & 67 & 70,5 & 95 & 63,3 & $P=0,78$ \\
\hline iyi & 1 & 20,0 & 8 & 80,0 & 10 & 6,7 & \\
\hline $\begin{array}{l}\text { HT beslenme } \\
\text { alma durumu }\end{array}$ & e ilaç & eğitimi & & & & & \\
\hline Alan & 17 & 23,6 & 55 & 76,4 & 72 & 48,0 & $\mathrm{P}=0,14$ \\
\hline Almayan & 27 & 34,6 & 51 & 65,4 & 78 & 52,0 & \\
\hline HT bilgi düzey & & & & & & & \\
\hline Yetersiz & 32 & 80,0 & 8 & 20,0 & 40 & 26,7 & $P=0,001$ \\
\hline Yeterli & 12 & 10,9 & 98 & 89,1 & 110 & 73,3 & \\
\hline Günlük alınan & ilaç sa & ayısı & & & & & \\
\hline 1-2 ilaç & 12 & 24,5 & 37 & 75,5 & 49 & 32,7 & \\
\hline 3-4 ilaç & 13 & 35,1 & 24 & 64,9 & 37 & 24,6 & $P=0,56$ \\
\hline 5 ve üzeri & 19 & 29,7 & 45 & 70,3 & 64 & 42,7 & \\
\hline Eğitim düzeyi & & & & & & & \\
\hline Okuryazar deği & 19 & 54,3 & 16 & 45,7 & 35 & 23,3 & \\
\hline İlköğretim & 19 & 23,8 & 61 & 76,3 & 80 & 53,4 & $P=0,001$ \\
\hline Lise ve üzeri & 6 & 17,1 & 29 & 82,9 & 35 & 23,3 & \\
\hline HT kontrol sık & liğl & & & & & & \\
\hline Ayda $1 \mathrm{kez}$ & 12 & 25,5 & 35 & 74,5 & 47 & 31,3 & \\
\hline 3 ayda 1 kez & 21 & 28,8 & 52 & 71,2 & 73 & 48,7 & $P=0,75$ \\
\hline 6 ayda $1 \mathrm{kez}$ & 4 & 40,0 & 6 & 60,0 & 10 & 6,7 & \\
\hline $\begin{array}{l}\text { Yılda } 1 \text { kez ve } \\
\text { altı }\end{array}$ & 7 & 35,0 & 13 & 65,0 & 20 & 13,3 & \\
\hline $\begin{array}{l}\text { Kendi kendine } \\
\text { yapma durum }\end{array}$ & TA öl & lçümü & & & & & \\
\hline Hergün & 11 & 25,6 & 32 & 74,4 & 43 & 28,7 & \\
\hline Haftada $1 \mathrm{kez}$ & 17 & 28,8 & 42 & 71,2 & 59 & 39,3 & $P=0,72$ \\
\hline
\end{tabular}

\begin{tabular}{|c|c|c|c|c|c|c|}
\hline Ayda $1 \mathrm{kez}$ & 16 & 33,3 & 32 & 66,7 & 48 & 32,0 \\
\hline \multicolumn{7}{|c|}{ HT tanı süresi } \\
\hline $0-3$ yıl arası & 13 & 40,6 & 19 & 59,4 & 32 & 21,3 \\
\hline $3-5$ yıl arası & 5 & 20,8 & 19 & 79,2 & 24 & $16,0 \quad P=0,23$ \\
\hline$>5$ yll & 26 & 27,7 & 68 & 72,3 & 94 & 62,7 \\
\hline \multicolumn{7}{|c|}{ Kan basıncı kontrol durumu } \\
\hline $\begin{array}{l}\text { SKB kontrol } \\
\text { altında }\end{array}$ & 18 & 31,0 & 40 & 69,0 & 58 & $38,7 \quad P=0,72$ \\
\hline $\begin{array}{l}\text { SKB kontrol } \\
\text { altında değil }\end{array}$ & 26 & 28,3 & 66 & 71,7 & 92 & 61,3 \\
\hline $\begin{array}{l}\text { DKB kontrol } \\
\text { altında }\end{array}$ & 22 & 28,2 & 56 & 71,8 & 78 & $52,0 \quad \mathrm{P}=0,75$ \\
\hline $\begin{array}{l}\text { DKB kontrol } \\
\text { altında değil }\end{array}$ & 22 & 30,6 & 50 & 69,4 & 72 & 48,0 \\
\hline
\end{tabular}

SKB: sistolik kan basıncı DKB. Diyastolik kan basıncı

Katılımcların antihipertansif tedaviye uyumunu etkileyen faktörleri incelediğimizde 65 yaş ve üzerinde olan katılımcıların ilaç uyumunun daha düşük olduğu görüldü. $(\mathrm{p}=0.04)$ HT bilgi düzeyi düşük olan katılımcların antihipertansif tedavi uyumlarının da düşük olduğu görüldü. $(\mathrm{p}=0,001)$ Antihipertansif tedaviye istatistiksel olarak anlamlı düzeyde etki eden diğer bir faktör ise katılımcıların eğitim düzeyi idi. Okuryazar olmayan katılımclların \%54,3'ü $(n=19)$ antihipertansif tedaviye düşük uyum göstermekteydi.(p=0,001) (Tablo 3).

Katılımcların Hipertansiyon (HT) bilgi düzeyine etki eden faktörleri incelediğimizde sadece eğitim düzeyinin istatistiksel olarak anlamlı düzeyde etki ettiği görüldü. Okuryazar olmayan katılımcıların HT bilgi düzeyi istatistiksel olarak anlamlı düzeyde düşük saptandl.(p=0,001) (Tablo 4). 
Tablo 4. HT bilgi düzeyinin katılımcıların bazı özellikleri ile ilișkisi

\begin{tabular}{|c|c|c|c|c|c|c|c|}
\hline \multirow{2}{*}{\begin{tabular}{|l} 
Özellikler \\
Cinsiyet
\end{tabular}} & \multicolumn{2}{|c|}{$\begin{array}{l}\text { Yetersiz } \\
\text { bilgi } \\
\text { düzeyi }\end{array}$} & \multicolumn{2}{|c|}{$\begin{array}{l}\text { Yeterli } \\
\text { bilgi } \\
\text { düzeyi }\end{array}$} & \multicolumn{2}{|c|}{ Toplam } & \multirow[t]{2}{*}{ İstatistik } \\
\hline & Sayı & Yüzde & Sayı & Yüzde & Sayı & Yüzde & \\
\hline Kadın & 23 & 33,8 & 45 & 66,2 & 68 & 45,3 & $P=0,07$ \\
\hline Erkek & 17 & 20,7 & 65 & 79,3 & 82 & 54,7 & \\
\hline \multicolumn{8}{|l|}{ Yaş } \\
\hline$<65$ yaș & 17 & 20,2 & 67 & 79,8 & 84 & 56,0 & $P=0,04$ \\
\hline$\geq 65$ yaş & 23 & 34,8 & 43 & 65,2 & 66 & 44,0 & \\
\hline \multicolumn{8}{|c|}{$\begin{array}{l}\text { Ek Kronik hastalık } \\
\text { bulunma durumu }\end{array}$} \\
\hline Var & 36 & 27,5 & 95 & 72,5 & 131 & 87,3 & $\mathrm{P}=0.55$ \\
\hline Yok & 4 & 21,1 & 15 & 78,9 & 19 & 12,7 & \\
\hline \multicolumn{8}{|c|}{ Gelir algısı durumu } \\
\hline Kötü & 11 & 24,4 & 34 & 75,6 & 45 & 30,0 & \\
\hline Orta & 25 & 26,3 & 70 & 73,7 & 95 & 63,3 & $P=0,59$ \\
\hline İyi & 4 & 40,0 & 6 & 60,0 & 10 & 6,7 & \\
\hline \multicolumn{8}{|c|}{$\begin{array}{l}\text { HT beslenme ve ilaç } \\
\text { eğitimi alma durumu }\end{array}$} \\
\hline Alan & 18 & 25,0 & 54 & 75,0 & 72 & 48,0 & $P=0,66$ \\
\hline Almayan & 22 & 28,2 & 56 & 71,8 & 78 & 52,0 & \\
\hline \multicolumn{8}{|c|}{ Günlük alınan ilaç sayısı } \\
\hline 1-2 ilaç & 9 & 18,4 & 40 & 81,6 & 49 & 32,7 & \\
\hline 3-4 ilaç & 10 & 27,0 & 27 & 73,0 & 37 & 24,7 & $\mathrm{P}=0,23$ \\
\hline 5 ve üzeri & 21 & 32,8 & 43 & 67,2 & 64 & 42,6 & \\
\hline \multicolumn{8}{|c|}{ Eğitim düzeyi } \\
\hline $\begin{array}{l}\text { Okuryazar } \\
\text { değil }\end{array}$ & 18 & 51,4 & 17 & 48,6 & 35 & 23,3 & \\
\hline İlköğretim & 16 & 20,0 & 64 & 80,0 & 80 & 53,3 & $P=0,001$ \\
\hline $\begin{array}{l}\text { Lise ve } \\
\text { üzeri }\end{array}$ & 6 & 17,1 & 29 & 82,9 & 35 & 23,3 & \\
\hline
\end{tabular}

\begin{tabular}{|c|c|c|c|c|c|c|c|}
\hline \multicolumn{8}{|c|}{ HT kontrol sıklığı durumu } \\
\hline $\begin{array}{l}\text { Ayda } 1 \\
\text { kez }\end{array}$ & 11 & 23,4 & 36 & 76,6 & 47 & 31,3 & \\
\hline $\begin{array}{l}3 \text { ayda } 1 \\
\text { kez }\end{array}$ & 16 & 21,9 & 57 & 78,1 & 73 & 48,7 & $\mathrm{P}=0,13$ \\
\hline $\begin{array}{l}6 \text { ayda } 1 \\
\text { kez }\end{array}$ & 5 & 50,0 & 5 & 50,0 & 10 & 6,7 & \\
\hline $\begin{array}{l}\text { Yılda } 1 \\
\text { kez ve altı }\end{array}$ & 8 & 40,0 & 12 & 60,0 & 20 & 13,3 & \\
\hline \multicolumn{8}{|c|}{$\begin{array}{l}\text { Kendi kendine TA ölçüm } \\
\text { durumu }\end{array}$} \\
\hline Hergün & 10 & 23,3 & 33 & 76,7 & 43 & 28,7 & \\
\hline $\begin{array}{l}\text { Haftada } 1 \\
\text { kez }\end{array}$ & 16 & 27,1 & 43 & 72,9 & 59 & 39,3 & $\mathrm{P}=0,81$ \\
\hline $\begin{array}{l}\text { Ayda } 1 \\
\text { kez }\end{array}$ & 14 & 29,2 & 34 & 70,8 & 48 & 32,0 & \\
\hline \multicolumn{8}{|c|}{ HT tanı alma süresi } \\
\hline $\begin{array}{l}0-3 \text { yıl } \\
\text { arası }\end{array}$ & 9 & 28,1 & 23 & 71,9 & 32 & 21,3 & \\
\hline $\begin{array}{l}3-5 \text { yıl } \\
\text { arası }\end{array}$ & 6 & 25,0 & 18 & 75,0 & 24 & 16,0 & $P=0,97$ \\
\hline$>5$ yll & 25 & 26,6 & 69 & 73,4 & 94 & 62,7 & \\
\hline
\end{tabular}

Katılımcların HT bilgi puanı ile antihipertansif tedaviye uyum puanı arasında istatistiksel olarak anlaml bir korelasyon saptandi. $(\mathrm{p}<0,001)$ (Tablo 5).

Tablo 5. Antihipertansif tedavi uyum puanı ile HT bilgi puanı arasında ki ilișki

\begin{tabular}{|lll|}
\hline & $\begin{array}{l}\text { Antihipertansif } \\
\text { tedavi } \\
\text { uyum puanı }\end{array}$ & HT bilgi puanı \\
\hline $\begin{array}{l}\text { Antihipertansif } \\
\text { tedavi uyum } \\
\text { puanı }\end{array}$ & 1 & $\mathrm{r}=0,887^{* *}$ \\
& & $\mathrm{p}<001$ \\
HT bilgi puanı & $\mathrm{r}=0,887^{* *}$ & 1 \\
& $\mathrm{p}<001$ & \\
\hline
\end{tabular}

**. Correlation is significant at the 0.01 level (2-tailed). $\mathrm{r}=$ spearmans's correlation coefficient 


\section{TARTIŞMA}

Araştırmamızda antihipertansif tedaviye uyumun hala önemli bir sorun olduğundan yola çıkarak hipertansiyonun (HT) hem kronik böbrek yetmezliğine (KBY) sebep olması hem de mevcut hastalığın son dönem böbrek yetmezliğine gidişatını hızlandırdığı bilinen hasta grubunda antihipertansif ilaç tedavisine uyum oranlarını incelemek amaçlanmıștır. Literatürde antihipertansif tedaviye uyum ile ilgili çalışmalar mevcut iken KBY'li hasta grubunda yapılmış bir çalışmaya rastlanılmamıștır. Bizde bu bağlamda antihipertansif tedaviye uyumun daha iyi olmasını, farkındalığın normal hipertansif hasta popülasyonundan yüksek olmasını beklediğimiz grupta güncel durumu incelemek ve literatürde veri bulunmayan bu gruba özel bilgileri elde etmeyi amaçladık.

Araștırmamızda katılımcıların \%70,6'sının antihipertansif ilaç tedavisine yeterli uyum sağladıkları görülmüştür. Ülkemizde yapılan çalışmalara baktığımızda sırasıyla \%86,8, $\% 77,4$ ve $\% 86$ oranında antihipertansif ilaç tedavisine uyum oranları bildirilmiştir ${ }^{22-24}$. Yurt dişında yapılan araştırmalara baktığımızda Uchmanowicz ve ark literatür taraması sonucu elde ettikleri 13 araştırmanın sistematik incelemesinde antihipertansif ilaç tedavisine uyum oranlarını $\% 66,99$ ile $\% 73,20$ aralığında bildirmişlerdir ${ }^{25}$. Araştırmamızdan elde ettiğimiz $\% 70,6$ oranında ki antihipertansif ilaç tedavisine uyum oranı literatür ile benzerlik göstermiștir. Antihipertansif tedavinin hastalık seyrini ve prognozu olumsuz etkilediği ve son dönem böbrek yetmezliğine ilerleyişi hızlandırdığı göz önüne alındığında KBY'si olan hasta grubunun normal popülasyondan daha fazla antihipertansif ilaç tedavisine uyum göstermesi beklenirken maalesef katılımcı grubumuzun antihipertansif ilaç tedavisine uyumunun normal popülasyondan farklı olmadığı saptanmıștır.
Antihipertansif tedaviye uyumu etkileyen faktörleri incelediğimizde cinsiyet ve gelir düzeyi algısının istatistiksel olarak anlamlı bir etkisi olmadığı görülmüştür. Ülkemizde ilaç uyumu ile ilgili yapılan çalışmalarda elde ettiğimiz bulgular ile benzer şekilde cinsiyet ve gelir düzeyi ile ilaç uyumu arasında anlamlı ilişki olmadığı bildirilmiştir ${ }^{23,24,26}$. Yurt dişında yapılan 13 çalışmanın derlendiği metaanaliz çalışmasında da bulgularımıza benzer şekilde cinsiyet ve gelir düzeyinin antihipertansif tedavi uyumu ile ilişkisine rastlanmamıştır ${ }^{25}$.

Araştırmamızda 65 yaş ve üzeri katılımcıların antihipertansif tedaviye uyumlarının istatistiksel olarak anlamlı düzeyde 65 yaş altı bireylerden daha düşük olduğu görülmüştür. Literatür taramasında yaş ile antihipertansif tedaviye uyum arasında karışık bir ilişki olduğu görülmüștür. Ülkemizde yapılan çalışmada yaş ile tedaviye uyum arasında istatistiksel olarak anlamlı bir ilişki olmadığı görülmüştür ${ }^{22}$. Yurt dışında yapılan yayınların derlendiği bir metaanaliz çalışmasında ise 15 çalışmada yaşlandıkça ilaç uyumunun arttığı bildirilmiştir ${ }^{25}$. Yaşlandıkça ilaç uyumunun artmasını genel olarak HT’a eşlik eden hastalıkların artması sonucu kişilerin hastalık algılarının artması ile ilişkilendirilmiştir. Araştırmamızda eşlik eden hastalık sayısının artmasının ilaç uyumuna etkisinin olmadığı görülmüştür ve literatür verilerinde ki eşlik eden hastalık arttıkça ilaç uyumunun artması yönünde ki bulgu desteklenememiștir. Araştırmamızda eşlik eden hastalık durumu sorgulanmasına rağmen kişilerin hastalık algılarının sorgulanmaması çalışmamızın kısıtlılığı olduğu ve bu yüzden konunun aydınlatılabilmesine yeterince katkı sağlanamadığı düşünülmüştür. $\mathrm{Bu}$ verilerin aksine 2 farklı çalışmada ise yaşlandıkça ilaç uyumunun azaldığ yaşlılığa bağlı fonksiyonel ve mental kapasitede azalmadan kaynaklanabileceği bildirilmiştir ${ }^{27,28}$. Çalışmamız ve literatür verileri değerlendirildiğinde yaş ile ilaç uyumu 
ilişkisinin hala net olarak açıklanamadığ söylenebilir. İleride yapılacak çalışmalarda literatürde ki hipotezler dikkate alınarak konunun daha derinlemesine araştırılması gerektiği düşünülmüştür.

Araştırmamızda günlük kullanılan ilaç sayısının antihipertansif tedaviye uyumu etkilemediği görülmüştür. Ülkemizde Şahin ve ark ile Tekinemre ve ark. yaptıkları araştırmalarda bulgularımızla benzer şekilde kullanılan ilaç sayısının tedaviye uyuma istatistiksel olarak anlamlı etkisinin olmadığını bildirmişlerdir ${ }^{26,29}$. Yurt dışında yapılan 13 benzer araştırmada Jonkowska ve ark ile Teshoma ve ark. kullanılan ilaç sayısı arttıkça antihipertansif tedaviye uyumun azaldığını diğer çalışmalarda ise ilaç sayısı ile antihipertansif ilaç uyumu arasında uyum olmadığı bildirilmiștir ${ }^{25}$. Her ne kadar elde ettiğimiz veriler ve literatür verilerinin çoğunluğu kullanılan ilaç sayısının antihipertansif tedaviye uyum üzerinde etkisi olmadığını göstermiş olsa da aksi yöndeki literatür verileri de dikkate alınarak konunun ilerleyen çalışmalarda daha ayrıntılı ele alınması gerektiği düşünülmüştür.

Araştırmamızda ek kronik hastalık durumunun antihipertansif tedaviye uyum düzeyini etkilemediği görülmüştür. Ülkemizde Esirgen ve ark $^{23}$ ile Tekinemre ve ark. ${ }^{29}$ ile yurt dışında Hashmi ve ark. yaptığı araștırmada çalışmamızla benzer şekilde ek kronik hastalıkların tedavi uyumu ile ilişkisine rastlanmadığı bildirilmiştir ${ }^{30}$. Ülkemizde Akgül ve ark eşlik eden hastalık durumunun antihipertansif tedaviye uyumu arttırdığını bunun sebebinin ise hastaların tedaviye daha bilinçli yaklaşmaları ve artan ilaç sayısının tedaviyi olumlu etkilemesi olduğunu bildirmişlerdir ${ }^{31}$. Her ne kadar elde ettiğimiz bulgular genel literatür verileri ile uyumlu olsa da araştırmamızda artan ilaç sayısının tedaviye etkisinin olmaması ve ek kronik hastalıkların katılımcıların tedaviye bilinçli yaklaşım konusunda ki etkisini araştırmamış olmamız Akgül ve ark. tarafından elde edilen bulgulardan farklı sonuçlar elde etmemizin sebebi olabilir. Bu bağlamda Akgül ve ark. hipotezlerinin incelenebilmesi için çalışmamızda değerlendirilmeyen ek hastalıkların katılımcıların tedaviye bilinçli yaklaşımı üzerinde ki etkisinin araştırılması gerektiği düşünülmüştür.

Araştırmamızda eğitim düzeyinin istatistiksel olarak anlamlı düzeyde antihipertansif tedaviye uyumu etkilediği görülmüştür. Eğitim düzeyi azaldıkça antihipertansif tedaviye uyumun da azaldığı saptanmıştır. Eğitim ile ilgili yapılan çalışmalara baktığımızda Lulebo ve ark. ${ }^{32}$ (zayıf bilgi düzeyinin antihipertansif tedaviye uyumsuzluğu 2.4 kat arttırdığını, HT hasta eğitiminin verilmemesinin ise tedaviye uyumsuzluğu 1.7 kat arttırdığını bildirmiștir. Ramli ve ark. ${ }^{33}$ ise sağlık okuryazarlık düzeyi arttıkça katılımcıların antihipertansif tedaviye uyumunun arttığını bildirmişlerdir. Yine yurt dışında yapılan çalışmalara baktığımızda hasta ile ilgili faktörlerden eğitim düzeyinin antihipertansif tedaviye uyumu etkilediği ve eğitim düzeyi arttıkça uyumun arttığı bildirilmiştir ${ }^{25}$. Ülkemizde yapılan 2 farklı çalışmada eğitim düzeyi ve antihipertansif tedaviye uyum arasında ilişkiye rastlamadıklarını ama bunun en önemli sebebinin katılımcıların büyük kısmının okuma yazma bilmeyen ve ilköğretim mezunu kişilerden oluşmasından kaynaklandığını bildirmişlerdir ${ }^{22,23}$. Literatür ile uyumlu olarak elde ettiğimiz veriler ışığında eğitim düzeyinin ilaç uyumunu arttıran bir faktör olduğu kanaatine varılmıştır.

Araştırmamızda HT bilgi puanı yüksek olan katılımcıların ve eğitim düzeyi yüksek olan katılımcıların ilaç uyumlarının yüksek olması bize HT beslenme ve ilaç eğitimi verilen kişilerde ilaç uyumunun daha yüksek olabileceğini düşündürmesine rağmen araştırmamızda HT beslenme ve ilaç eğitimi alan ve almayan katılımcılar arasında ilaç uyumu arasında fark olmadığı görülmüștür. Literatürde Kim Y34 ve ark tarafından 3802 
hipertansif hasta üzerinde yapılan çalışmada hastalığının farkında olan katılımcıların hem ilaç uyumlarının hem de kan basıncı kontrollerinin daha iyi olduğunu bildirmişlerdir ${ }^{34}$. Ülkemizde Esirgen ve ark tarafından yapılan çalışmada da benzer şekilde hastalıkları hakkında bilgi düzeyi yüksek katılımcıların tedavi uyumlarının daha yüksek olduğu bildirilmiştir ${ }^{24}$. Hastalık farkındalığının yüksek olmasını beklediğimiz KBY'li hasta grubumuzda HT eğitimi almayan bireylerin olması ve HT eğitimi alsa dahi tedaviye uyuma etki etmemesi beklenmedik bir sonuç olarak değerlendirilmiștir. Katılımcılara sadece eğitim alıp almadıklarının sorgulanması, HT hakkında bilgi düzeylerinin sorgulanmaması araştırmamızın kısıtlıklarından birisi olduğu ve hasta eğitiminin tedaviye uyum üzerindeki etkisini açıklama konusunda yetersiz kaldığımızı düşündürmüştür.

Araştırmamızda kişilerin HT için doktor kontrol sıklığının ve kendi kendilerine ölçüm yapma sıklıklarının tedaviye uyum üzerine etkisine rastlanmamıştır. Yurt dışında Balasubramanian ve ark yaptığı araştırmada bulgularımızla benzer şekilde hekim kontrol sıklığı ve kendi kendine ölçüm yapma sıklığının tedaviye uyum üzerine etkisine rastlanmadığ bildirilmiştir ${ }^{35}$. Ülkemizde ise Kaya ve ark benzer şekilde hekim ziyareti ile uyum arasında ilişki olmadığını fakat hekim ziyaretinde hastanın bilgilendirilmesinin ve motive edilmesinin tedaviye uyumu arttırabileceği belirtilmiştir ${ }^{24}$. Literatür ile uyumlu olarak hekim ziyaretinin tedaviye uyum üzerine etkisi olmadığ görülmüștür ve bundan sonra yapılacak araştırmalarda hekim ziyaret sıklığın yanında hekim ziyaretinin içeriğinin tedaviye uyumunun araştırılmasının konunun aydınlatılmasına daha fazla katkı sağlayabileceği düşünülmüştür.

Araştırmamızda ilaç tedavisine uyum oranlarının \%70,6 olmasina rağmen katılımcıların diyastolik kan basınçları $\% 48$ ve sistolik kan basınçları ise \%61 oranında kontrol altında olmadığı saptanmıştır. Literatürde çalışmamızda elde ettiğimiz bulgulara benzer şekilde ilaç uyumundan daha düşük oranlarda kan basıncı kontrolü sağlandığı bildirilmiştir ${ }^{23}$. Hipertansiyon tedavisinin sadece medikal tedaviden ibaret olmaması ve yaşam tarzı değişiklikleri ve beslenme alışkanlıklarının kan basıncına etkisi düşünüldüğünde kan basıncı regülasyonu konusunda ilaç uyumundan daha kötü sonuçlar elde etmemiz beklenen bir bulgu olabilir. Kan basıncının kontrolünün değerlendirilmesinde ilaç uyumu ile birlikte beslenme ve yașam tarzının da mutlaka dikkate alınması gerektiği düşünülmüștür.

\section{Kısitlılıklarımız}

Araştırmamızın tek bir merkeze başvuran hastalarda yapıldığından elde ettiğimiz bulguların genel popülasyonu yansıtması beklenemez. Araștırmamıza dahil edilen KBY'li hasta grubumuzun hastalık farkındalığının ve bilgi düzeyinin KBY'si olmayan hasta grubundan daha yüksek olması gerektiğini düşünmemize rağmen hipotezimizi destekleyecek herhangi bir farkındalık ve bilgi düzeyi ölçümü yapılmamıştır. Elde ettiğimiz ilaç uyum oranlarının normal HT hasta popülasyonu ile benzerlik göstermesi hastalarımızın farkındalık ve bilgi düzeyinin beklendiği şekilde yüksek olmama olasıllğını düşündürmüștür.

\section{SONUÇ}

Araştırmamızda antihipertansif tedaviye uyumun daha fazla önem arz ettiği KBY'li hasta grubunda ilaç uyumunun yetersiz olduğunu göstermiştir. Eğitim seviyesinin düşüklüğü, hastalık hakkında yeterince bilgi sahibi olmama ve yaşlılığın ilaç uyumunu olumsuz yönde etkilediği görülmüştür. Eğitim ve bilgi eksikliğinin olumsuz etkisi bir kez daha Aile Hekimliğinin olmazsa olmazlarından hastanın güçlendirilmesi ve hasta ve sağllk eğitiminin önemini vurgulamış ve bu ilkeleri uygulayarak hastalarımıza daha etkin sağlık hizmeti sunabileceğimiz düşünülmüștür. 
Çıkar Çatışması Beyanı: Yazarlar çıkar çatışması olmadığını bildirmişlerdir.

Finansal Destek: Bu çalışma her hangi bir fon tarafından desteklenmemiştir.

Declaration of Conflicting Interests: The authors declare that they have no conflict of interest.

Financial Disclosure: No financial support was received.

\section{KAYNAKLAR}

1. Mancia G, Fagard R, Narkiewicz K, et al. Task Force for the Management of Arterial Hypertension of the European Society of Hypertension and the European Society of Cardiology. 2013 ESH/ESC Practice Guidelines for the Management of Arterial Hypertension. Blood Press 2014; 23: 3-16.

2. Yoon SS, Fryar CD, Carroll MD. Hypertension Prevalence and Control Among Adults: United States, 2011-2014.NCHS Data Brief 2015; 220: 1-7.

3. Türkiye Kalp ve Damar Hastalıkları Önleme ve Kontrol Programı. Eylem Planı 2015-2020. Ankara T.C. Sağlık Bakanlığı Türkiye Halk Sağlığı Kurumu. Anıl Reklam Matbaa Ltd. Şti, 2015:p.16.

4. Man Ș, Güven GS. Güncel klavuzlar eşliğinde hipertansiyon tedavisi. Hacettepe Tip Dergisi 2011; 42: 53-64.

5. Altun B, Arici M, Nergizoğlu G, et al. Turkish Society of Hypertension and Renal Diseases: Prevalence, awareness, treatment and cont-rol of hypertension in Turkey (the PatenT study) in 2003. J Hypertens 2005; 23: 1817-23.

6. Arici M, Turgan C, Altun B, et al. Hypertension incidence in Turkey (HinT): a population-based study. J Hypertens 2010; 28: 240-4. https://dx.doi.org/10.1097/HJH.0b013e328332c36b

7. Teke N, Arslan S. Kırsal Alanda Yaşayan Hipertansiyonlu Bireylerin İlaç Tedavisine Uyum Özyetkililik Düzeyleri ve Etkileyen Faktörlerin Belirlenmesi. Dokuz Eylül Üniversitesi Hemşirelik Fakültesi Elektronik Dergisi 2018; 11:120-8.

8. Chobanian AV, Bakris GL, Black HR, et al. The Seventh Report of the Joint National Committee on Prevention, Detection, Evaluation, and Treatment of High Blood
Pressure: the JNC 7 report. JAMA 2003; 289: 2534-73. (PubMed)

9. Cheng JW, Kalis MM, Feifer S. Patient-reported adherence to guidelines of the sixth joint national committee on prevention, detection, evaluation, and treatment of high blood pressure. Pharmacotherapy 2001; 21: 828-41. (PubMed)

10. Ünalan PC, Çifçili S, Uzuner A, et al. Hastaların Hipertansiyon ve Antihipertansifler Konusundaki Alg1 ve inanışları. Türk Aile Hek Derg 2005; 9: 153-8.

11. Hacıhasanoğlu R. Factors affecting compliance in hypertansion. TAF preventive Medicine Bulletin 2009; 2: 167-72.

12. Okan, A. Bolu valiliği yaşlı merkezine kayıtlı 65 yaş ve üstü kişilerin hipertansiyon farkındalığı ve evde bakım uygulamaları. Yüksek Lisans Tezi Abant İzzet Baysal Üniversitesi Sağlık Bilimleri Enstitüsü. Bolu. 2010

13. Arıcı M, Altun M, Erdem Y, et al. Türk Hipertansiyon ve Böbrek Hastalıkları Derneği. Patent çalışması. 2003. Erișim adresi: http://www.turkhipertansiyon.org/pdf/Turk_Hipertan siyon_Prevalans_Calismasi_Ozeti-1.pdf

14. Uzun Ş, Kara B, Yokuşoğlu M, et al. Hipertansiyonlu bireylerin tedavi ve yaşam biçimi değişimine uyumlarının değerlendirilmesi. Anadolu Kardiyol Derg 2009; 9(2): 102-9. (PubMed)

15. Kamran A, Sadeghieh AS, Ahari S, et al. Determinants of patient's adherence to hypertension medications: application of health belief model among rural patients. Ann Med Health Sci Res 2014; 4(6) : 922-7. (PubMed)

16. Koçoğlu D, Gedik S. Kırsal alanda yaşayan hipertansif bireylerin hastalık yönetimlerinin değerlendirilmesi. Akademik Sosyal Araştırmalar Dergisi 2016; 4: 207-18.

17. Mills KT, Xu Y, Zhang W, et al. A systematic analysis of worldwide population-based data on the global burden of chronic kidney disease in 2010. Kidney Int. 2015; 88(5): 950-7. (PubMed)

18. Muntner P, Anderson A, Charleston J, et al. Hypertension awareness, treatment, and control in adults with CKD: results from the Chronic Renal Insufciency Cohort (CRIC) Study. Am J Kidney Dis. 2010; 55(3): 441-51. (PubMed)

19. Allen AS, Forman JP, Orav EJ, et al. Primary care management of chronic kidney disease. J Gen Intern Med. 2011; 26(4): 386-92. (PubMed)

20. Lv J, Ehteshami P, Sarnak MJ, et al. Effects of intensive blood pressure lowering on the progression of chronic kidney disease: a systematic review and meta-analysis. CMAJ. 2013; 185(11): 949-57. (PubMed) 
21. Vural B, Acar ÖT, Topsever P, Filiz TM. Modifiye Morisky ölçeğinin geçerlilik güvenilirlik çalıșması. The Journal of Turkish Family Physician 1999; 3: 17-20.

22. Mert H, Özçakar N, Kuruoğlu E. Multidisipliner bir özel çalışma modülü araştırması: Hipertansiyon hastalarının tedaviye uyumlarının incelenmesi. Turk Aile Hek Derg 2011; 15(1): 7-12.

23. Esirgen L. Hipertansif bireylerin tedaviye uyum ve yaşam değişikliği başarısını değerlendirme ölçeğinin geliștirilmesi. İstanbul Üniversitesi Cerrahpaşa Tıp Fakültesi Halk Sağlı̆̆ı. Uzmanlık tezi. İstanbul. 2018

24. Kaya E.P. Hipertansiyon tanılı hastaların ilaç uyumunun değerlendirilmesi. Ankara Atatürk eğitim Araștırma Hastanesi Aile Hekimliği Kliniği. Uzmanlık Tezi. Ankara.2016

25. Uchmanowicz B, Jankowska EA, Uchmanowicz I, et al. Self-Reported Medication Adherence Measured With Morisky Medication Adherence Scales and Its Determinants in Hypertensive Patients Aged_60 Years: A Systematic Review and Meta-Analysis. Front Pharmacol. 2019; 10:168. (PubMed)

26. Sahin NS. Hipertansiyon yönetiminde hasta uyumu ve hastaların sağlık anlayışlarına yönelik bir girişimin uyum üzerine etkisi. Uzmanlık Tezi. 2015.

27. Ross S, Walker A, MacLeod MJ. Patient compliance in hypertension: Role of illness perceptions and treatment beliefs. J Hum Hypertens. 2004; 18(9): 607-13. (PubMed)

28. Enlund H, Jokisalo E, Wallenius S, et al. Patientperceived problems, compliance, and the outcome of hypertension treatment. Pharm World Sci. 2001; 23: 60. https://doi.org/10.1023/A:1011204216548
29. Tekinemre IG. Hipertansif hastalarda tedavi uyumu, tedavi uyumunu etkileyen faktörlerin incelenmesi ve yaşam kalitelerinin değerlendirilmesi. İnönü üniversitesi Tıp Fakültesi Aile Hekimliği. Uzmanlık tezi, Malatya, 2019.

30. Hashmi SK, Afridi MB, Abbas $K$, et al. Factors associated with adherence to anti-hypertensive treatment in Pakistan. PloS One. 2007; 2(3): e280. (PubMed)

31. Akgül C. Hipertansiyon hastalarında antihipertansif uyumun değerlendirilmesi. İstanbul Üniversitesi Cerrahpaşa Tıp Fakültesi. Uzmanlık tezi, İstanbul, 2008.

32. Lulebo A. Mutombo M, Mapatano PM, et all. Predictors of non-adherence to antihypertensive medication in Kinshasa, Democratic Republic of Congo: a cross-sectional study. BMC research notes. 2015; 8: 526-34.

33. Ramli A, Ahmad NS, Paraidathathu T. Medication adherence among hypertensive patients of primary health clinics in Malaysia. Patient preference and adherence. 2012; 6: 613-24.

34. Kim Y, Kong KA. Do hypertensive individuals who are aware of their disease follow lifestyle recommendations better than those who are not aware? PloS one. 2015; 10: 1-13.

35. Balasubramanian A, Nair SS, Rakesh PS, Leelamoni K. Adherence to treatment among hypertensives of rural Kerala, India. J Family Med Prim Care. 2018; 7: 64-9. 